\title{
Effects of uterine cervix constriction on Wistar rats ${ }^{1}$
}

\author{
Efeitos da constrição do cérvix uterino em ratos Wistar
}

\author{
Cassio Eduardo Raposo-Amaral', Ana Beatriz Almeida ${ }^{\mathrm{II}}$, Cesar Augusto Raposo-Amaral', Luiz Carlos Vulcano ${ }^{\mathrm{III}}$, Maria Rita \\ Passos-Bueno $^{\text {Iv }}$, Nivaldo Alonsov
}

${ }^{\mathrm{I}} \mathrm{MD}$, Plastic Surgeon, Institute of Craniofacial and Plastic Surgery, SOBRAPAR, Campinas-SP, Brazil.

${ }^{\text {II }} \mathrm{PhD}$, Biologist, Institute of Craniofacial and Plastic Surgery, SOBRAPAR, Campinas-SP, Brazil.

${ }^{\text {III }} \mathrm{PhD}$, Full Professor, Veterinary Medicine, State University of Sao Paulo (UNESP), Botucatu-SP, Brazil.

${ }^{\text {Iv }}$ PhD, Full Professor, Department of Genetics and Evolution Biology, Institute of Biosciences, USP, Sao Paulo, Brazil.

${ }^{v}$ MD, PhD, Associate Professor, Plastic Surgery Division, Department of Surgery, USP, Sao Paulo, Brazil.

\begin{abstract}
Purpose: To verify if uterine cerclage can induce craniosynostosis or any cranial deformity in new born Wistar rats. Methods: One pregnant female Wistar rat underwent laparotomy on day 18 of gestation and the uterus cervix was closed with a 3-0 nylon suture to avoid delivery, that occurs normally on the 21 day. The suture was released after 48 hours beyond the normal gestation period. The female rat delivered 11 pups. Six surviving rats from the delivery (group A - constrained group). Two rats were born from another mother and in the same age were used as control group (group B - 2 nonconstrained controls) were allowed to grow. They were sacrificed 1.2 years after their birth all the eight animals. Linear measurement, routine histology and computed tomography of the skull were performed at the time of their death to evaluate the cranial asymmetries by mesurements of the anatomical landmarks of the craniofacial skeleton of the rats on the two groups and compared then. Results: We did not observe statistically significant differences in any of the compared measurements ( $>0.05$ ) obtained through the morphologic and radiologic methods. Histologic examinations did not reveal any sign of premature fusion or suture imbrications. Critical decrease in longitudinal body size was noticed as the limbs too in all the animals of group A. Conclusion: Constriction of uterine cervix leads to fetus suffering, even death for a few animals, associated to small body size, but not to craniosynostosis.
\end{abstract}

Key words: Craniosynostoses. Cerclage, Cervical. Surgery, Plastic. Rats.

\section{RESUMO}

Objetivo: Verificar se a cerclagem intra-uterina pode induzir, ao nascimento de ratos Wistar, craniossinostose ou qualquer outra deformidade craniana. Métodos: Uma rata Wistar prenhe foi submetida à laparotomia no $18^{\circ}$ dia de gestação e o cérvix uterino foi suturado com 3-0 nylon, impedindo o parto normal que normalmente ocorre no $21^{\circ}$ dia de gestação. A sutura foi liberada 48 horas após o período gestacional normal. A rata gestante deu à luz 11 animais. Seis ratos sobreviveram ao parto (grupo A com restrição). Dois ratos nascidos de outra mãe e com a mesma idade foram utilizados como controle (grupo B sem restrição controle) durante o seu crescimento. Os oito animais foram sacrificados após 1,2 ano. Medidas lineares, histologia e tomografia computadorizada foram utilizadas para a aferição de assimetrias cranianas através da mensuração de pontos anatômicos do esqueleto craniofacial dos ratos dos dois grupos. Resultados: Não foi observada diferença estatisticamente significante entre as medidas obtidas nos ratos dos dois grupos $(\mathrm{p}>0,05)$ obtidas através de métodos morfológicos e radiológicos. As análises histológicas não revelaram sinais de fusão prematura da suturas do crânio. Diminuição do segmento corpóreo, bem como do tamanho dos membros foi evidenciado em todos os animais do grupo A. Conclusão: A restrição do cérvix uterino levou ao sofrimento fetal, morte de alguns animais e diminuição do tamanho do corpo de todos os animais, mas não craniossinostose.

Descritores: Craniossinostose. Cerclagem Cervical. Cirurgia Plástica. Ratos.

${ }^{1}$ Research performed at the Institute of Craniofacial and Plastic Surgery, SOBRAPAR and Plastic Surgery Division, Department of Surgery, University of Sao Paulo (USP).

\section{Introduction}

Several theories explain the premature fusion of the cranial sutures in non syndromic craniosynostosis. Potential causes that may trigger the premature fusion of the cranial sutures are suggested and may vary from metabolic derangement to maternal hyperthyroidism, hypercalcemia, or idiophatic deficit in brain growth ${ }^{1}$. Martínez-Lage et al. ${ }^{2}$ have linked neural tube defect to the premature fusion of the cranial sutures. They advocated that the decrease in intra cranial pressure and in brain pulsation may 
lead to suture imbrication, causing synostosis². However, mechanical forces that somehow constrict the fetal head during the third trimester of gestation are considered to be a main cause of non syndromic forms of craniosynostosis. Clinical studies have emphasized the fetal head constraint as an important etiology in craniosynostosis development ${ }^{1,3}$.

Experimental studies have shown the effects of the replication of mechanical forces on producing premature fusion of the cranial sutures, by postponing the normal gestation period beyond 24 hours ${ }^{4}$. Nevertheless, fetal head constraint is not widely accepted as a main etiology for cranial suture fusion in non syndromic craniosynostosis. Bradley et al. ${ }^{5}$ have tested the mechanical restrictive uterine forces to reproduce suture fusion in a lamb model. They have observed craniofacial skeleton deformation with patency of cranial sutures and not craniosynostosis.

The purpose of this study was to verify if uterine cerclage can induce craniosynostosis or any cranial deformity in Wistar rats.

\section{Methods}

Pregnant female Wistar rats underwent laparotomy on day 18 of gestation and the uterus cervix was closed with a 3-0 nylon suture under anesthesia, using an intramuscular injection $(0.3 \mathrm{~mL} / 100 \mathrm{~g}$ of body weight) with a combination of ketamine hydrochloride (5\%) and xylazine (2\%) (Figure 1).

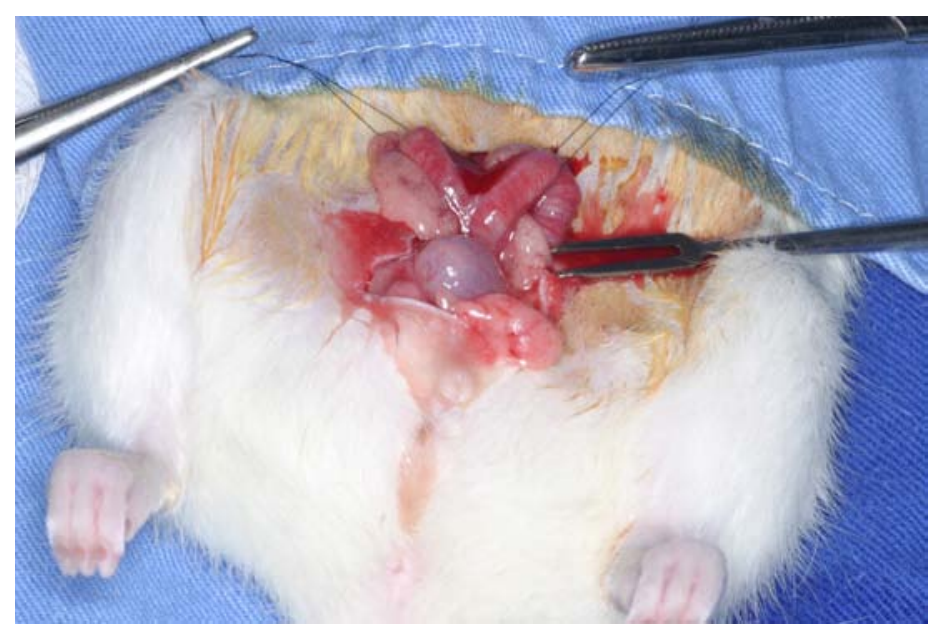

FIGURE 1 - Intraoperative photography of uterine cerclage at day 18 of gestation

The suture was released after 48 hours beyond the normal 21 days gestation period. Six hours after the suture was released, the female rats delivered 11 pups. Six of 11 pups survived the severe maternal stress. Five dead pups were removed from their mothers and compared to nonconstrained controls, which had been delivered normally on day 21 of gestation. The craniofacial skeleton of the five dead pups received gross inspection and the skull specimens were sent to histological examination.

The six pups that survived the severe maternal stress (three males and three females) and two nonconstrained controls (1 male and 1 female) were followed until the adult age.
The six animals of the experimental group as well as the two animals of the control group were sacrificed at 1.2 years after their birth. Gross inspection and computerized tomography and histological evaluation were done in all animals.

The experimental protocol was approved by the Animal Research Ethics Committee of the Institution under the protocol 1980-1. The animals were housed in standardized air and light conditions at constant temperature of $22^{\circ} \mathrm{C}$ with 12-hour light/day cycle. They had free access to tap drinking water and standard laboratory food pellets.

\section{Histologic analysis}

Samples of the craniofacial skeleton of each animal were prepared for histologic analysis. The specimens samples were fixed in $10 \%$ formalin for 24 hours, decalcified in 5\% formic acid for 48 hours, embedded in paraffin, and sectioned at the thickness of $5 \mu \mathrm{m}$. Sagittal and coronal sections through the cranial base were stained with hematoxylin and eosin to evaluate the premature fusion of the coronal and sagittal sutures as well as the cranial base sutures. Morphologic measurements

Three distances were standardized based on the calvarial sutures. Two distances transversally and one sagitally.

Tranversally: Landmarks for morphologic measurements of the coronal suture were established in the insertion of temporalis muscle. Landmarks for morphologic measurements of the lambdoid suture were established in the bone bridge between temporal bone and occipital bone visible in rats' calvaria (Figure 2).

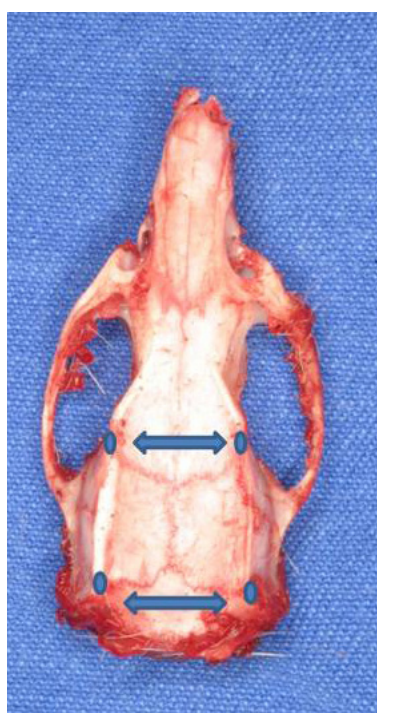

FIGURE 2 - The superior view of dissected craniofacial skeleton of adult age rats that had undergone fetal constraint. Note the landmarks for morphologic measurements of the coronal and lambdoid suture

Sagittaly: Landmarks for sagittal morphologic measurements were established in the imbrications of coronal and lambdoid sutures. The anatomical points were marked with methylene blue and the measurements were performed in 3 consecutive times and averaged (Figure 3). 


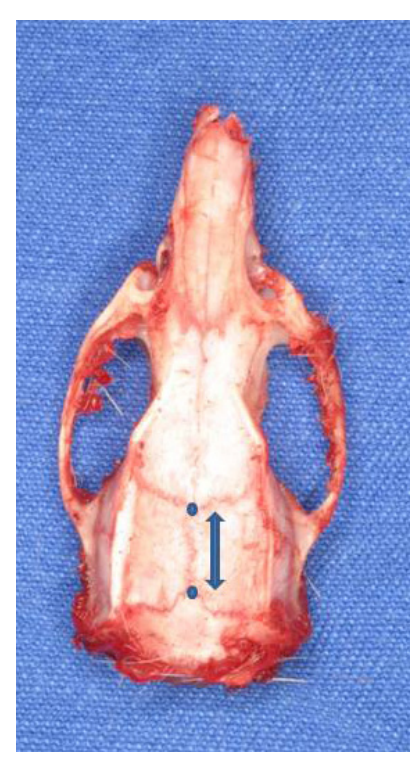

FIGURE 3 - The superior view of dissected craniofacial skeleton of adult age rats that had undergone fetal constraint. Note the landmarks for morphologic measurements of the sagittal suture

The distances were measured using a small caliper.

\section{Computerized tomography}

Imaging of the craniofacial skeleton of the Wistar rats were taken at adult age. Rats were sacrificed minutes before the examination. Scans were reconstructed as three-dimensional imaging isosurfaces using InVesalius software, developed by DT3D (Division of Tridimensional Tecnology) - CTI - Brazil. Four distances transversally and two distances sagitally were determined as standards and measured based on well-defined anatomical points.

Transversally: Landmarks for radiologic measurements were established in the union point of zygomatic arch and zygomatic process of the maxilla (ZA-ZPM); the union of coronoid processes of the mandible coinciding with the pterygoid bone in the cranial base (CPM); the union of left and right tympanic cavities (TC); and the union point of zygomatic arch and parietal cranial bones (ZA-PB).

Sagitally: Landmarks for radiologic measurements were established at the union of two points formed by the junction between zygomatic arch and zygomatic process of the maxilla and the junction formed by zygomatic arch and parietal cranial bones. Measurements were taken at left and right sides (LSD; left sagittal distance and RSD; right sagittal distance).

\section{Statistical analysis}

The values of the measurements obtained by the CT scans and morphologic measurements were averaged and compared separately to those measurements obtained from the controls using an One-way ANOVA test. The probability value of less than 0.05 was considered as significant. For statistical analysis, we used SPSS V16 software.

\section{Results \\ Gross findings}

The five rats which were born dead had their skull exposed. Visual inspection did not reveal any evidence of synostosis in the coronal, lamboid and sagital sutures. The six rats which survived the severe maternal stress caused by uterine cerclage had a very small longitudinal size in comparison with their pairs in the control group and relatively shorter upper and lower limbs. Head shape was normal in all of them, with no evidence of synostosis (Figure 4).

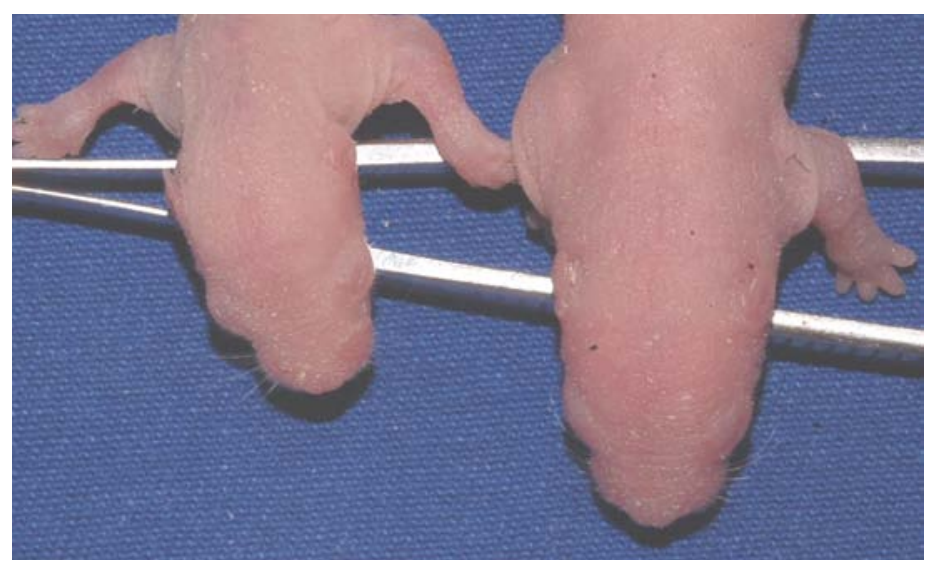

FIGURE 4 - The superior oblique view of a fetal head constrained pup and age-matched control pup. Note that the difference in longitudinal body size is quite significant

Interestingly, during the growth spurt, rats which were offsprings of the constrained group "caught up" to the normal growth level observed in the controls, therefore they had almost the same size of the craniofacial skeleton and weight at adult age. Gross inspection of the craniofacial skeleton did not reveal any alteration of the skull shape, as well as no obliteration of cranial sutures.

We did not observe statistically significant differences in any of the measurements of the craniofacial skeleton taken with the caliper in either group: the female rats or the male rats, both at adult age $(\mathrm{p}>0.05)$. All measurements performed with a caliper were shown in Table 1.

TABLE 1 - Each anatomic landmark measured with caliper

\begin{tabular}{cccc}
\hline Distances (caliper) & $\begin{array}{c}\text { Coronal suture } \\
(\mathrm{mm})\end{array}$ & $\begin{array}{c}\text { Lambdoid suture } \\
(\mathrm{mm})\end{array}$ & $\begin{array}{c}\text { Coronal -Lambdoid } \\
\text { suture }(\mathrm{mm})\end{array}$ \\
\hline F.C & 12 & 13 & 8 \\
F 1 & 12 & 13 & 8.1 \\
F 2 & 12 & 13 & 6.5 \\
F 3 & 11.5 & 12.5 & 7.2 \\
M.C & 11.5 & 12.5 & 8.3 \\
M 1 & 12.5 & 13.3 & 9 \\
M 2 & 12 & 13 & 10.2 \\
M 3 & 12 & 13 & 7.6 \\
\hline
\end{tabular}

F.C, female control; M.C, male control; F (1-3) = females and $\mathbf{M}$ (1-3) $=$ males born after uterine cerclage 


\section{Histological findings}

We did not observe any sign of premature ossification neither in coronal nor sagittal sutures.

\section{Radiographic findings}

We did not observe statistically significant differences in any of the measurements taken through CT scans (Figure 5 and Table 2).

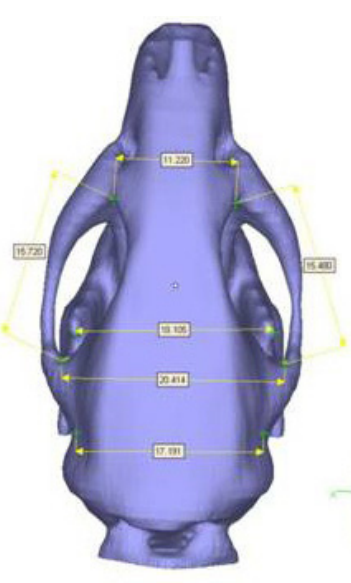

Female Control

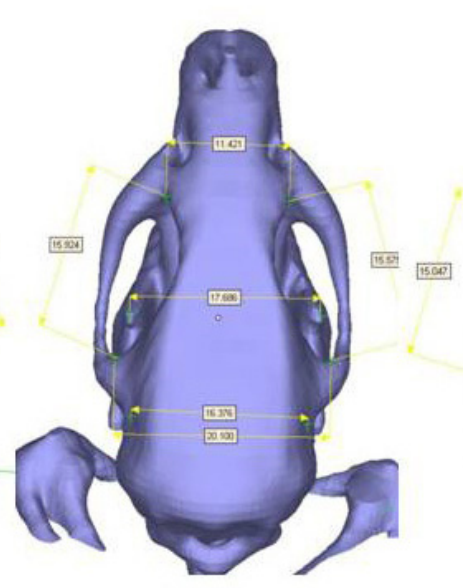

Female 1

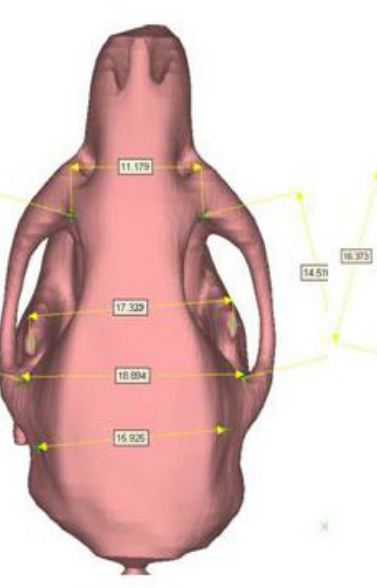

Female 2

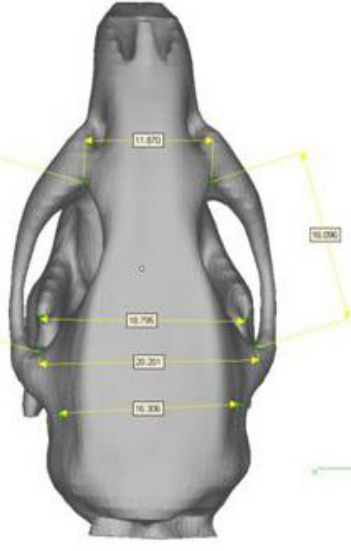

Female 3

FIGURE 5 - Computed tomography images showing superior view of the craniofacial skeleton of female rat borne of restrained mother and that of its age-matched from the control group at 1 year and 2 months of age. Note landmarks of radiologic measurements

TABLE 2 - Each anatomic landmark measured with CAT scan

\begin{tabular}{ccccccc}
\hline Distances & $\begin{array}{c}\text { ZA-ZPM } \\
(\mathrm{mm})\end{array}$ & $\begin{array}{c}\text { CPM } \\
(\mathrm{mm})\end{array}$ & $\begin{array}{c}\text { TC } \\
(\mathrm{mm})\end{array}$ & $\begin{array}{c}\text { ZA-PB } \\
(\mathrm{mm})\end{array}$ & $\begin{array}{c}\text { LSD } \\
(\mathrm{mm})\end{array}$ & $\begin{array}{c}\text { RSD } \\
(\mathrm{mm})\end{array}$ \\
\hline FC & 11.220 & 18.105 & 20.414 & 17.191 & 15.720 & 15.480 \\
F1 & 11.421 & 17.686 & 16.376 & 20.100 & 15.924 & 15.575 \\
F2 & 11.179 & 17.379 & 18.894 & 15.925 & 15.047 & 14.516 \\
F3 & 11.870 & 18.795 & 20.201 & 16.306 & 16.373 & 16.096 \\
MC & 13.490 & 20.205 & 21.184 & 18.111 & 16.642 & 16.722 \\
M1 & 12.935 & 19.888 & 19.366 & 18.376 & 16.350 & 16.317 \\
M2 & 12.124 & 18.477 & 19.898 & 16.654 & 16.155 & 15.777 \\
M3 & 12.613 & 19.235 & 19.878 & 17.407 & 16.653 & 15.617 \\
\hline
\end{tabular}


Distance ZA-ZPM corresponded to the union point of zygomatic arch and zygomatic process of the maxilla $(\mathrm{p}=0.668)$; distance CPM corresponded to the union of coronoid processes of the mandible coinciding with the pterygoid bone in the cranial base $(\mathrm{p}=0.525)$; distance TC corresponded to the union of left and right tympanic cavities ( $\mathrm{p}=0.164)$; distance $\mathrm{ZA}-\mathrm{PB}$ corresponded to the union point of zygomatic arch and parietal cranial bones $(\mathrm{p}=0.880$ ); distances LSD and RSD corresponded to the union of two points formed by the junction between zygomatic arch and zygomatic process of the maxilla and the junction formed by zygomatic arch and parietal cranial bones at left and right sides $(p=0.844)$ and $(\mathrm{p}=0.448)$.

\section{Discussion}

No study, which has evaluated the long-term effects of the uterine cerclage on the shape of the craniofacial skeleton in Wistar rat model was found in the current literature.

Investigators have identified abnormal patterns of TGF-ß expression in a model of fetal head constraint. They demonstrated that mechanical forces caused by intrauterine cerclage up-regulates TGF- $\$ 1$ in osteoblasts of the involved cranial suture and downregulates its dural TGF- $\$ 3^{4,6}$. This phenomenon associated to chondrocyte apoptosis was also seen in the spheno-occipital synchondrosis, suggesting morphologic skeletal changes in the cranial base sutures ${ }^{7}$. These experimental studies corroborate other clinical studies which suggest that non syndromic forms of craniosynostosis might have started in the primary premature fusion of the cranial base sutures ${ }^{8-11}$. Additionally, it also has been suggested that the premature fusion resulted from a relative constriction of the fetal head in the maternal pelvis and it has been stated that the fetal head constraint is a main etiology for sagittal synostosis $^{3}$.Uterine compressing mechanical forces may cause fetal anoxia and may lead to severe maternal stress. In a preliminary attempt we had $100 \%$ mortality rate in a series of C-sections. Therefore, instead of a C-section, we released the uterine cerclage 48 hours beyond the normal gestation and we let the mother deliver normally. We significantly decreased the mortality rate with this maneuver, where five out of eleven pups were born dead due to the severe uterine anoxia that was imposed on the pups during the last days of gestation. Indeed, uterine anoxia may have innumerous consequences and not only craniosynostosis.

The body size of the rats of constrained mothers was significantly smaller than that of the age-matched controls, at the time of birth. No evidence of craniofacial changes were seen, thus the absence of uterine oxygen might have caused an impairment of the body growth, but not craniosynostosis. At the time of their death, the Wistar adult rats had similar weight and size to that of their age-matched controls, demonstrating that there was no long-term effects on growth. We may have to maintain the uterine cerclage for a longer period of time, not only 48 hours beyond the normal gestation day, to be able to observe more dramatic skeletal changes.

Warren et al. ${ }^{12}$ have described the importance of Noggin expression in suture patency ${ }^{12}$.Subsequently, Jacob et al. ${ }^{13}$ have described the effects of the down regulation of the expression of Ihh and Noggin on non syndromic forms of craniosynostosis induced by fetal head constraint in a rodent model ${ }^{13}$. Ihh has also played a major role in the development of long bones ${ }^{14}$. Although we did not test Ihh expression, it may explain the smaller size of upper and lower limbs observed in the Wistar rats. A selective pathway that resulted on impairment of long bones development might have happened.

Jaskoll et al. ${ }^{15}$ have evaluated the consequences of fetal constraint in vitro on cranial base and other skeletal components. They have found craniofacial deformation, as well as vertebral column and long bones deviations ${ }^{15}$. A variability of bony modifications was observed in fetal head constraint model. Further studies of long term effects of uterine cerclage on the entire skeleton are needed in order to quantify the bony alterations found after severe fetal anoxia

\section{Conclusion}

Constriction of uterine cervix leads to fetus suffering, even death for a few animals, associated to small body size, but not to craniosynostosis in Wistar Rats. Further investigations were needed to determine the causes of non-syndromic craniosynostosis.

\section{References}

1. Graham JM, Jr., Badura RJ, Smith DW. Coronal craniostenosis: fetal head constraint as one possible cause. Pediatrics. 1980;65(5):995-9.

2. Martinez-Lage JF, Poza M, Lluch T. Craniosynostosis in neural tube defects: a theory on its pathogenesis. Surg Neurol. 1996;46(5):465-9; discussion 469-70.

3. Graham JM, Jr., deSaxe M, Smith DW. Sagittal craniostenosis: fetal head constraint as one possible cause. J Pediatr. 1979;95(5 Pt 1):74750.

4. Kirschner RE, Gannon FH, Xu J, Wang J, Karmacharya J, Bartlett SP, Whitaker LA. Craniosynostosis and altered patterns of fetal TGF-beta expression induced by intrauterine constraint. Plast Reconstr Surg. 2002;109(7):2338-46; discussion 2347-54.

5. Bradley JP, Shahinian H, Levine JP, Rowe N, Longaker MT. Growth restriction of cranial sutures in the fetal lamb causes deformational changes, not craniosynostosis. Plast Reconstr Surg. 2000;105(7):2416-23.

6. Hunenko O, Karmacharya J, Ong G, Kirschner RE. Toward an understanding of nonsyndromic craniosynostosis: altered patterns of TGF-beta receptor and FGF receptor expression induced by intrauterine head constraint. Ann Plast Surg. 2001;46(5):546-53; discussion 553-4.

7. Smartt JM, Jr., Karmacharya J, Gannon FH, Teixeira C, Mansfield K, Hunenko O, Shapiro IM, Kirschner RE. Intrauterine fetal constraint induces chondrocyte apoptosis and premature ossification of the cranial base. Plast Reconstr Surg. 2005;116(5):1363-9.

8. Moss ML. Functional anatomy of cranial synostosis. Childs Brain. 1975;1(1):22-33.

9. Moss ML. The pathogenesis of premature cranial synostosis in man. Acta Anat (Basel). 1959;37:351-70.

10. Rosenberg P, Arlis HR, Haworth RD, Heier L, Hoffman L, LaTrenta G. The role of the cranial base in facial growth: experimental craniofacial synostosis in the rabbit. Plast Reconstr Surg. 1997;99(5):1396-407.

11. Putz DA, Smith TD, Burrows AM, Cooper GM, Dechant J, Losken HW, Siegel MI, Mooney MP. Cranial base changes following coronal suturectomy in craniosynostotic rabbits. Orthod Craniofac Res. 2002;5(2):90-103.

12. Warren SM, Brunet LJ, Harland RM, Economides AN, Longaker MT. The BMP antagonist noggin regulates cranial suture fusion. Nature. 2003;422(6932):625-9.

13. Jacob S, Wu C, Freeman TA, Koyama E, Kirschner RE. Expression of Indian Hedgehog, BMP-4 and Noggin in craniosynostosis induced by fetal constraint. Ann Plast Surg. 2007;58(2):215-21. 
14. St-Jacques B, Hammerschmidt M, McMahon AP. Indian hedgehog signaling regulates proliferation and differentiation of chondrocytes and is essential for bone formation. Genes Dev. 1999;13(16):2072-86.
15. Jaskoll T, Melnick M. The effects of long-term fetal constraint in vitro on the cranial base and other skeletal components. Am J Med Genet. 1982;12(3):289-300.

\section{Correspondence:}

Nivaldo Alonso

Rua Afonso Brás, 473/conj. 65

04511-011 São Paulo - SP Brasil

nivalonso@gmail.com.br

Conflict of interest: none

Financial source: none

Received: March 23, 2010

Review: May 18, 2010

Accepted: June 16, 2010

\section{How to cite this article}

Raposo-Amaral CE, Almeida AB, Raposo-Amaral CA, Vulcano LC, Passos-Bueno MR, Alonso N. Effects of uterine cervix constriction on Wistar rats. Acta Cir Bras. [serial on the Internet] 2010 Nov-Dec;25(6). Available from URL: http://www.scielo.br/acb

*Color figures available from www.scielo.br/acb 